\title{
Amide Bond Cleavage: The Acceleration Due to a 1,3-Diaxial Interaction with a Carboxylic Acid
}

\author{
Jared J. Gerschler ${ }^{\dagger}$, Kevin A. Wier ${ }^{\ddagger}$, and David E. Hansen§, \\ Department of Chemistry, Amherst College, Amherst, Massachusetts 01002, and Polymer Science \\ and Engineering Department, University of Massachusetts, Amherst, Massachusetts 01003
}

\begin{abstract}
To independently assess the contribution of ground-state pseudoallylic strain to the enormous rates of amide bond cleavage in tertiary amide derivatives of Kemp's triacid, we have studied four amide derivatives of (1 $\alpha-3 \alpha-5 \beta)-5$ - $t$-butyl-1,3-cyclohexanedicarboxylic acid. Our results confirm that absent pseudoallylic strain, a 1,3-diaxial interaction of an amide with a carboxylic acid leads to only a 2,400-fold increase in the rate of amide bond cleavage as compared with the rate of hydrolysis of an unactivated peptide bond.
\end{abstract}

\begin{abstract}
In 1988, Menger and Ladika ${ }^{1}$ reported that the pyrrolidyl amide of Kemp's triacid (1a, Figure 1) undergoes intramolecular acylolysis with a half-life of 8 minutes at pD 7.05 and $21.5^{\circ} \mathrm{C}$. Only one of the two carboxylic acid functionalities directly participates in the reaction, as evidenced by, for example, the fact that the acid-ester-amide derivative $\mathbf{1 b}$ undergoes amide cleavage at a rate only slightly slower than diacid-amide 1a. The second acid functionality in 1a does, however, perturb the $\mathrm{p} K_{\mathrm{a}}$ of the first so that an appreciable concentration of reactive conjugate acid is present at neutrality. The anhydride $\mathbf{2}$ initially formed rapidly hydrolyzes, and thus the net transformation is formally the hydrolysis of an unactivated amide bond.
\end{abstract}

At neutral $\mathrm{pH}$ and $25^{\circ} \mathrm{C}$, the hydrolysis of an unactivated peptide bond has a half-life of roughly 500 years. ${ }^{2,3}$ The reaction is independent of buffer catalysis and likely involves the direct attack of water. Under these conditions, the rate of amide cleavage in Kemp's triacid derivative 1a is thus approximately 33-million-times faster, an increase that was initially attributed primarily to the "sustained proximity" of the carboxylic acid and amide functionalities. ${ }^{1}$

That only one carboxylic acid functionality is required for rapid amide cleavage was directly confirmed in 1990, when Menger and Ladika reported that monoacid-amide derivative 4 reacts at a rate comparable to that of $\mathbf{1 a}$ and $\mathbf{1} \mathbf{b} .^{4}$

\footnotetext{
dehansen@amherst.edu.

${ }^{\dagger}$ Amherst College; current address: School of Natural Science, Hampshire College, Amherst, MA 01002.

\$University of Massachusetts Amherst; current address: Dow Corning Corporation, Midland, MI 48686

$\S$ Amherst College.
} 


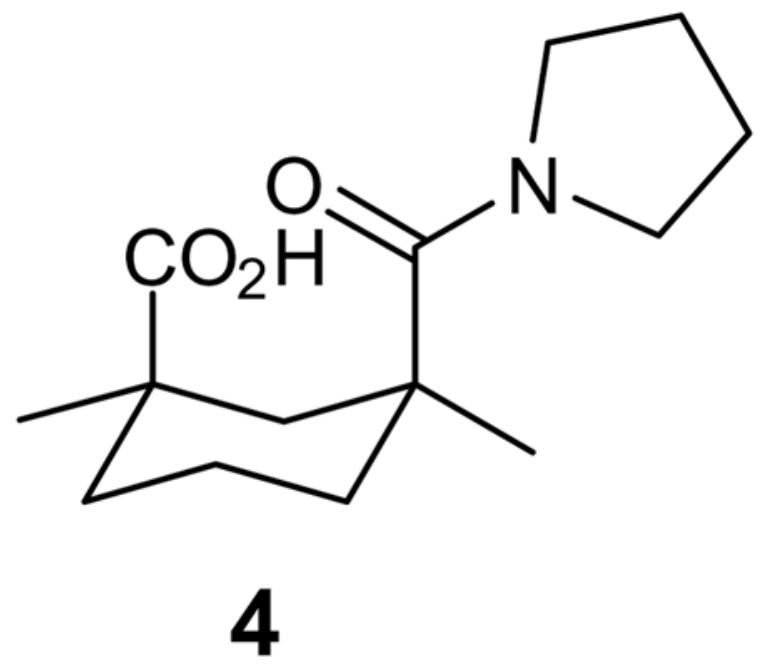

In 1994, Curran et al. ${ }^{5}$ demonstrated that the tertiary methylphenethyl amide of Kemp's triacid 5 undergoes intramolecular amide cleavage at a rate similar to that of Kemp's derivatives 1a and $\mathbf{1 b}$ but that the secondary phenethyl amide $\mathbf{6 a}$ reacts $10^{2}-10^{4}$ times more slowly, depending upon $\mathrm{pH}$. These workers therefore proposed that an important factor in the reactivity of the tertiary amide derivatives was the relief of "pseudoallylic (pseudo $\mathrm{A}^{1,3}$ ) strain" (the nonbonded interactions between the amide substituent trans to the carbonyl group and the neighboring methyl group on the cyclohexyl ring) upon intramolecular attack of the amide bond. (In accord with the earlier results noted above, the cleavage rate of $\mathbf{6 a}$ was found to be only slightly faster than that of the monomethyl ester $\mathbf{6 b}$.)

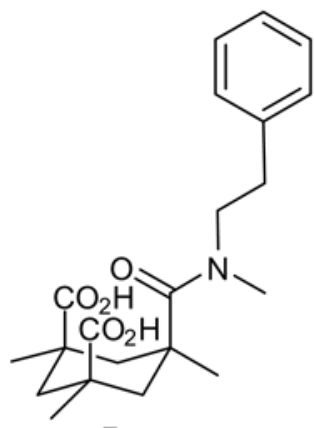

5

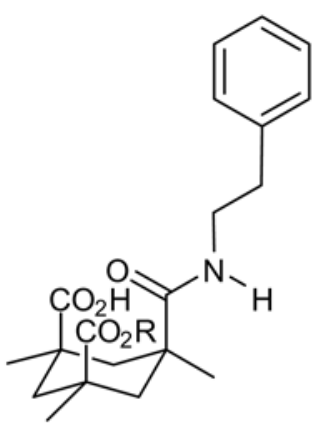

6a $\mathrm{R}=\mathrm{H}$

6b $\mathrm{R}=\mathrm{CH}_{3}$

To further investigate the reactivity of Kemp's diacid-amides, our group ${ }^{6}$ synthesized the piperidyl amide of Kemp's triacid (7). This derivative undergoes amide bond cleavage approximately four-times faster than pyrrolidyl derivative 1a. Molecular mechanics calculations suggested, consistent with the proposal of Curran et al., ${ }^{5}$ that this increase in rate is due to greater pseudoallylic strain in the amide ground state of derivative $\mathbf{7}$ as a result of increased nonbonded interactions with the pseudo-chair conformation of the piperidyl ring. 


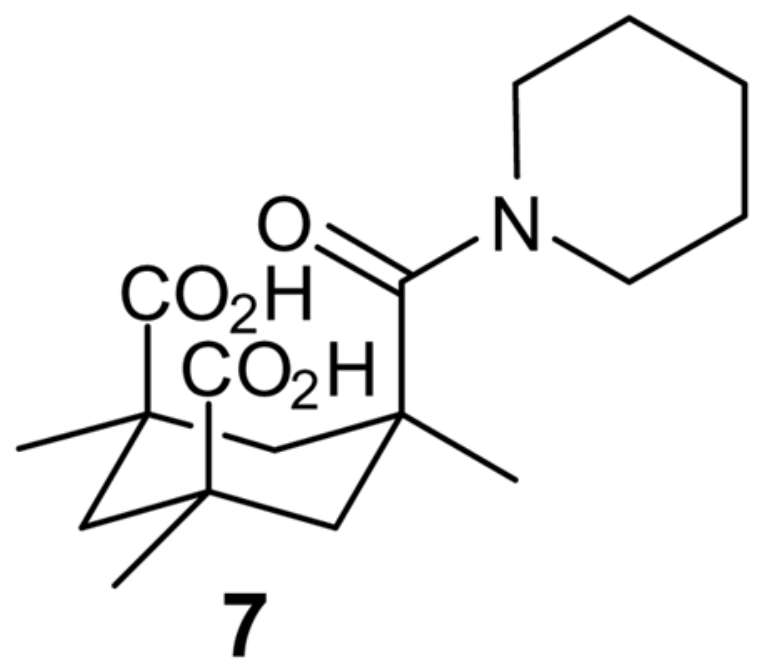

Given the potential significance of Menger and Ladika's observations to the catalytic mechanism of some proteases and to the design of artificial enzymes, we wished to independently probe the role of pseudoallylic strain in these systems. We report here the syntheses and reactivities of the $t$-butylcyclohexyl acid-amide derivatives 8-11. In comparison to amide derivatives of Kemp's triacid, pseudoallylic strain is reduced in these $t$-butyl derivatives, due to the absence of a methyl group geminal to the amide functionality; in particular, steric contacts are greatly minimized in secondary amide derivative $\mathbf{1 0}$ and primary amide derivative 11. The presence of the trans $t$-butyl group assures, of course, that the acid and amide functionalities in derivatives 8-11 are maintained in the 1,3-diaxial geometry. ${ }^{7}$<smiles>CC(C)(C)CC(CC(=O)N1CCCCC1)C(=O)O</smiles><smiles>CC(C)(C)CC(C(=O)O)C(=O)N1CCCC1</smiles><smiles>CCNC(=O)C1CC(C(=O)O)CC(C(C)(C)C)C1</smiles><smiles>CNC1CC(C(=O)C(C)C)C[C@H](C(C)(C)C)C1=O</smiles>

The above acid-amides were all synthesized directly from the trans-t-butylcyclohexyl anhydride $\mathbf{1 2}^{7,8}$ and the corresponding amine. 


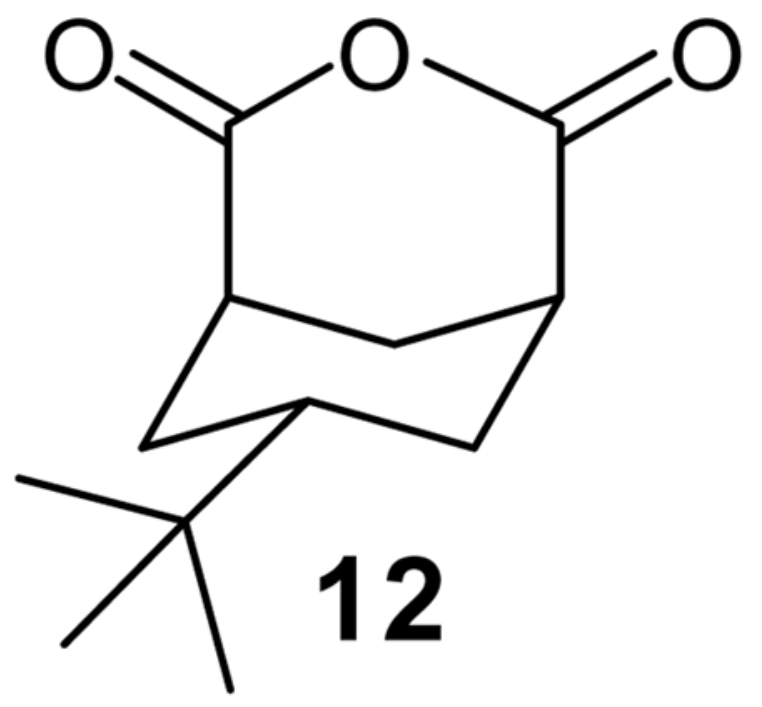

Compounds 8-11 were each dissolved in a small amount of DMSO- $\mathrm{d}_{6}$ and introduced into buffered $\mathrm{D}_{2} \mathrm{O}$ (at $\mathrm{pD} \sim 2.5, \sim 5.0$, and either $\sim 6.5$ for derivatives $\mathbf{1 0}$ and $\mathbf{1 1}$ or $\sim 7.5$ for derivatives 8 and 9 ), and the rate of amide-bond cleavage monitored by ${ }^{1} \mathrm{H}$ NMR. The kinetic data obtained at pD 5.5 for the $t$-butyl derivative 9 are plotted in Figure 2. (The rate constants measured at each $\mathrm{pD}$ for all of the derivatives 8-11 are listed in the Supporting Information.)

For derivatives 8-11, the pD-independent rate constant $\left(k_{\text {ind }}\right)$ and the apparent dissociation constant for the carboxylic acid functionality $\left(K_{\mathrm{a}}\right)$ were determined from a nonlinear Levenberg- Marquardt fit of the pD-rate data to the equation utilized by Curran et al.. 5

$$
\log \left(\mathrm{k}_{\text {obs }}\right)=\log \left[\left(\mathrm{k}_{\text {ind }} \mathrm{L}\right) /\left(K_{\mathrm{a}}+\mathrm{L}\right)\right],
$$

where $\mathrm{L}=\mathrm{D}_{3} \mathrm{O}^{+}$concentration. The $\mathrm{pD}$-rate profile for the cleavage of derivative 9 is shown in Figure 3 (the rates were measured at pD 3.0, 5.5, and 7.7 and the data fit to the above equation). Since the $\mathrm{p} K_{\mathrm{a}} \mathrm{s}$ of the Kemp's diacid-amide and of our $t$-butyl monoacid-amide derivatives may vary considerably (for example, Menger and Ladika ${ }^{1}$ estimated that the second $\mathrm{p} K_{\mathrm{a}}$ of Kemp's derivative 1a is 6.9 in $\mathrm{D}_{2} \mathrm{O}$ ), the values of $k_{\text {ind }}$ allow for a direct comparison of cleavage rates for the reactive conjugate acid protonation state. The $k_{\text {ind }}$ and $K_{\mathrm{a}}$ parameters obtained for derivatives 8-11 are listed in Table 1. Immediately evident from these data are the slow reaction rates for the sterically unencumbered $t$-butyl derivatives $\mathbf{1 0}$ and $\mathbf{1 1}$. Although not critical to the issue of pseudoallylic strain, the $K_{\mathrm{a}} \mathrm{s}$ obtained, including somewhat larger values for the tertiary amide derivatives, correspond well to the results obtained by Curran et al. 5

To explore further the structural features of the $t$-butylcyclohexyl derivatives 8-11, as well as of the Kemp's triacid derivatives 1a, 5, 6a, $\mathbf{6 b}$, and $\mathbf{7}$ discussed above, we employed molecular modeling calculations. Consistent with the earlier calculations of Menger and Ladika, ${ }^{1}$ the lowest-energy conformation found for all nine compounds has a carboxylic-acid carbonyl oxygen positioned near the amide-carbonyl carbon. Shown in Figure 4 are the minimized structures of Kemp's diacid-pyrrolidyl amide 1a and the corresponding $t$-butylcyclohexyl acidpyrrolidyl amide 9. Note that in comparison to the Kemp's triacid derivative 1a, the conformations of the carboxylic acid and amide functionalities are altered in the $t$-butyl derivative 9-absent the steric constraints afforded by the geminal methyl groups, these two substituents have rotated away from each other, and the distance between the carboxylic-acid 
carbonyl oxygen and the amide-carbonyl carbon has increased by $0.3 \AA$. A comparable increase in distance holds for all of the $t$-butylcyclohexyl derivatives 8-11.

The nonbonded interactions for each of the four $t$-butyl and five Kemp's triacid derivatives are given in Table 2 (the data are listed by derivative in order of increasing half-life for amide cleavage, as calculated from $k_{\text {ind }}$ ). For many of the derivatives, a number of low-energy structures were found, differing only in the conformation of the amide substituent-the close contact distances listed in Table 2 derive from the low-energy conformation with the leastsevere nonbonded interactions. Note as well that a second conformation, likely the reactive one, ${ }^{1}$ with the carboxylic acid hydroxyl group poised to both protonate and attack the amide functionality lies at slightly higher energy $(1-3 \mathrm{kcal} / \mathrm{mol})$ for all of the derivatives; the nonbonded interactions in these conformations are essentially identical to those listed in Table 2.

To determine the extent of the nonbonded interactions, we employed the values of $1.2 \AA$ for the van der Waals radius of a hydrogen bound to carbon and $1.0 \AA$ for hydrogen bound to nitrogen ("polar hydrogen") utilized by the Richardson group in their studies of amide side chain orientation in protein interiors. 9,10 For all the nine derivatives listed in Table 2, the data indicate that the number and severity of hydrogen-hydrogen close contact distances correlate well to the rate of amide cleavage. Shown in Figure 5, for example, are the nonbonded interactions in the minimized structures of derivatives $\mathbf{7}$ and $\mathbf{8}$. The Kemp's triacid derivative 7 , in which the two nonbonded interactions are more severe, reacts approximately 250- times faster than the corresponding $t$-butyl derivative $\mathbf{8}$.

A similar conclusion is reached from consideration of the nonbonded interactions in the secondary amide derivatives 6a and $\mathbf{1 0}$ shown in Figure 6. The Kemp's triacid derivative 6a reacts approximately 300-times faster than the $t$-butyl derivative $\mathbf{1 0}$ (we worked with the $t$ butyl ethyl amide, rather than the corresponding phenethyl amide, to achieve sufficient solubility in aqueous buffer). Both derivatives have a small nonbonded interaction of $2.1 \AA$, but the Kemp's triacid derivative has a second interaction on the cusp of a steric clash-the kinetic data suggest that this second interaction is enough to increase the cleavage rate significantly.

Finally, while other structural features in the above derivatives might be expected to lead to increased rates of amide cleavage, we have been unable to find another one that correlates with the kinetic data. For example, although each of the derivatives has a small out-of-plane distortion of the amide bond, ${ }^{11}$ no pattern is evident. Similarly, the "attack" distance between the carboxylic-acid carbonyl oxygen and the amide-carbonyl carbon (as shown in Figure 4 for derivatives 1a and 9) does not parallel reaction rate-in particular, the distance for $t$ butylcyclohexyl pyrrolidyl amide derivative 9 is almost $0.2 \AA$ longer than for the slowerreacting Kemp's phenethyl amide derivative 6a. (The values for the out-of-plane distortions and attack distances for each of the derivatives in Table 2 are provided in the Supporting Information.)

In conclusion, the results presented here on the $t$-butyl amide derivatives 8-11 further support the conclusion of Curran et al. ${ }^{5}$ that ground-state pseudoallylic strain plays an important role in the extraordinary reactivity of Kemp's diacid-tertiary amide derivatives. Moreover, our data allow us to estimate the rate increase of amide bond cleavage afforded by a 1,3-diaxial interaction with a carboxylic acid group in the absence of additional strain. Compared with the Kemp's diacid-pyrrolidyl amide 1a originally reported by Menger and Ladika, ${ }^{1}$ which has significant pseudoallylic strain, the $t$-butylcyclohexyl ethyl amide derivative 10, which has just a single, small nonbonded interaction, reacts 65,000-times more slowly (Table 2). In comparison with the hydrolysis of an unactivated peptide bond (half life of approximately 500 
years at $\mathrm{pH} 5-9^{2,3}$ ), derivative $\mathbf{1 0}$ reacts only 2,400-times faster, a small increase indeed given that enzyme-catalyzed peptide bond hydrolysis can occur with a rate acceleration of over $10^{13}$-fold. ${ }^{12}$

\section{Experimental Section}

trans-5-t-Butyl-1,3-cyclohexanedicarboxylic anhydride (12) was prepared as described in Refs. 7 and ${ }^{8}$. (The hydrogenation ${ }^{8}$ was run in a custom-built stainless steel reaction vessel that was pressurized with hydrogen gas to 2,600 psi at room temperature using an ISCO 100DM syringe pump. The vessel temperature was maintained at $240^{\circ} \mathrm{C}$ in a sand bath for $24 \mathrm{~h}$-at this temperature, the pressure of hydrogen gas is approximately 4,500 psi. The resultant 5-tbutyl-1,3-cyclohexanedicarboxylic acid, as a mixture of diastereomers, was converted into the $t$-butylcyclohexyl anhydride 12 by sublimation from phosphorus pentoxide. ${ }^{7}$ ) ${ }^{1} \mathrm{H} \mathrm{N} \mathrm{R}$ $\left(\mathrm{CDCl}_{3}, 400 \mathrm{~Hz}\right) \delta 3.14(\mathrm{~m}, 2 \mathrm{H}), 2.24-2.14(\mathrm{~m}, 3 \mathrm{H}), 1.70(\mathrm{dt}, J=13.6,2.2 \mathrm{~Hz}, 1 \mathrm{H}), 1.51(\mathrm{td}$, $J=13.2,2.9 \mathrm{~Hz}, 2 \mathrm{H}), 1.27(\mathrm{tt}, J=13.2,3.7 \mathrm{~Hz}, 1 \mathrm{H}), 0.86(\mathrm{~s}, 9 \mathrm{H}) ;{ }^{13} \mathrm{C} \mathrm{NMR}\left(\mathrm{CDCl}_{3}, 100\right.$ $\mathrm{MHz}) \delta 170.3,41.6,37.0,32.6,30.1,27.3,27.2$; IR $\left(\mathrm{CHCl}_{3}, \mathrm{~cm}^{-1}\right)$ 1026, 1233, 1759, 1806, 2364, 2872, 2966; HRMS (TOF ES+) calculated for $\mathrm{C}_{12} \mathrm{H}_{18} \mathrm{O}_{3}(\mathrm{M}+\mathrm{H})^{+}: 211.1334$. Found: 211.1341 .

\section{General Procedure for the Synthesis of the $\boldsymbol{t}$-butyl derivatives $\mathbf{8}$ and $\mathbf{9}$}

To $t$-butylcyclohexyl anhydride $12(42 \mathrm{mg}, 0.20 \mathrm{mmol})$ in $1.5 \mathrm{~mL} \mathrm{CH}_{2} \mathrm{Cl}_{2}$ were added the appropriate amine $(0.22 \mathrm{mmol})$ and triethylamine $(70 \mu \mathrm{L}, 0.50 \mathrm{mmol})$. The mixture was stirred at room temperature for $12 \mathrm{~h}$ under nitrogen. The reaction solution was then diluted with 10 $\mathrm{mL} \mathrm{CH}_{2} \mathrm{Cl}_{2}$ and washed with $3 \times 5 \mathrm{~mL} 1 \mathrm{M} \mathrm{HCl}$. The $\mathrm{CH}_{2} \mathrm{Cl}_{2}$ layer was dried over anhydrous $\mathrm{MgSO}_{4}$, filtered, and the solvent removed by evaporation under reduced pressure to yield the product.

\section{(1 $\alpha-3 \alpha-5 \beta)-5-t$-Butyl-3-(1-piperidylcarbonyl)cyclohexanecarboxylic acid (8)}

yield $20.1 \mathrm{mg}$ (67.9\%); clear colorless oil; ${ }^{1} \mathrm{H}$ NMR $\left(\mathrm{CDCl}_{3}, 400 \mathrm{MHz}\right) \delta 3.66-3.41(\mathrm{~m}, 4 \mathrm{H})$, $2.95(\mathrm{~m}, 1 \mathrm{H}), 2.77(\mathrm{~m}, 1 \mathrm{H}), 2.23-2.08(\mathrm{~m}, 2 \mathrm{H}), 1.90-1.78(\mathrm{~m}, 2 \mathrm{H}), 1.72-1.46(\mathrm{~m}, 7 \mathrm{H}), 1.44-1.31$ (m, 2H), 0.90 (s, 9H); ${ }^{13} \mathrm{C} \mathrm{NMR}\left(\mathrm{CDCl}_{3}, 100 \mathrm{MHz}\right) \delta 174.8(2 \mathrm{C}), 47.1,43.3,39.2,34.9,32.8$, 28.3, 27.73, 27.67, 27.4, 27.1, 26.8, 25.8, 24.8; IR $\left(\mathrm{CHCl}_{3}, \mathrm{~cm}^{-1}\right)$ 1228, 1446, 1586, 1617, $1705,2863,2946$; HRMS (TOF ES+) calcd for $\mathrm{C}_{17} \mathrm{H}_{29} \mathrm{NO}_{3}(\mathrm{M}+\mathrm{H})^{+}:$296.2225. Found: 296.2214 .

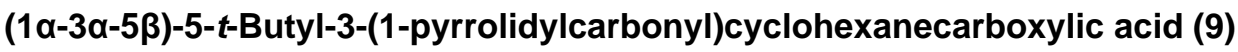

yield: $12.5 \mathrm{mg}$ (44.3\%); clear colorless oil; ${ }^{1} \mathrm{H} \mathrm{NMR}\left(\mathrm{CDCl}_{3}, 400 \mathrm{MHz}\right) \delta 3.47(\mathrm{~m}, 4 \mathrm{H}), 2.80$ (m, 2H), 2.18-2.07 (m, 2H), $1.96(\mathrm{~m}, 2 \mathrm{H}), 1.90-1.79(\mathrm{~m}, 4 \mathrm{H}), 1.75-1.56(\mathrm{br} \mathrm{s}, 1 \mathrm{H}), 1.41(\mathrm{~m}$, 2H), $0.88(\mathrm{~s}, 9 \mathrm{H}) ;{ }^{13} \mathrm{C} \mathrm{NMR}\left(\mathrm{CDCl}_{3}, 100 \mathrm{MHz}\right) \delta 175.4(2 \mathrm{C}), 46.9,46.4,39.0,37.2,32.8$, 27.8, 27.7, 26.6, 26.5, 24.4; IR $\left(\mathrm{CHCl}_{3}, \mathrm{~cm}^{-1}\right)$ 1228, 1441, 1586, 1617, 1711, 2873, 2967; HRMS (TOF ES+) calcd for $\mathrm{C}_{16} \mathrm{H}_{27} \mathrm{NO}_{3}(\mathrm{M}+\mathrm{H})^{+}:$282.2069. Found: 282.2070.

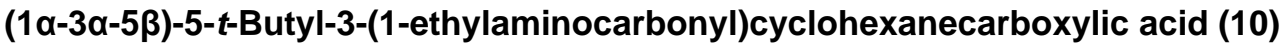

To $t$-butylcyclohexyl anhydride $12(7.5 \mathrm{mg}, 36 \mu \mathrm{mol})$ in $0.50 \mathrm{~mL} \mathrm{CH}_{2} \mathrm{Cl}_{2}$ were added a $2.0 \mathrm{M}$ solution of ethylamine in THF $\left(20 \mu \mathrm{L}, 40 \mu \mathrm{mol} \mathrm{EtNH}_{2}\right)$ and triethylamine $(14 \mu \mathrm{L}, 100 \mu \mathrm{mol})$. The mixture was stirred under nitrogen for $6 \mathrm{~h}$ at room temperature, and the product workedup as described above to yield $6.8 \mathrm{mg}(74.3 \%)$ of a clear, colorless oil. ${ }^{1} \mathrm{H}$ NMR (DMSO- $\mathrm{d}_{6}$, $400 \mathrm{MHz}) \delta 11.95(\mathrm{br} \mathrm{s}, 1 \mathrm{H}), 7.80(\mathrm{t}, J=4.8 \mathrm{~Hz}, 1 \mathrm{H}), 3.15(\mathrm{~m}, 2 \mathrm{H}), 2.62(\mathrm{~m}, 1 \mathrm{H}), 2.50(\mathrm{~m}$, $1 \mathrm{H}), 1.95-1.62(\mathrm{~m}, 5 \mathrm{H}), 1.51(\mathrm{~m}, 2 \mathrm{H}), 1.11(\mathrm{t}, J=7.3 \mathrm{~Hz}, 3 \mathrm{H}), 0.97(\mathrm{~s}, 9 \mathrm{H}) ;{ }^{13} \mathrm{C}$ NMR (DMSO$\left.\mathrm{d}_{6}, 100 \mathrm{MHz}\right) \delta 176.5,174.5,38.7,37.9,37.4,33.3,32.6,28.8,27.63,27.55,26.3,14.7$; IR 
$\left(\mathrm{CHCl}_{3}, \mathrm{~cm}^{-1}\right)$ 1224, 1516, 1662, 1704, 2874, 2958, 3445; HRMS (TOF ES+) calculated for $\mathrm{C}_{14} \mathrm{H}_{25} \mathrm{NO}_{3}(\mathrm{M}+\mathrm{H})^{+}:$256.1912. Found: 256.1924 .

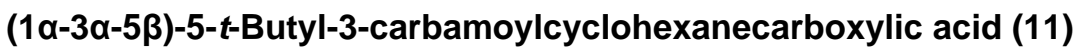

To $t$-butylcyclohexyl anhydride $12(10.5 \mathrm{mg}, 50 \mathrm{~mol})$ of in $0.75 \mathrm{~mL} \mathrm{CH}_{2} \mathrm{Cl}_{2}$ were added a 0.5 $\mathrm{M}$ solution of $\mathrm{NH}_{3}$ in dioxane $(150 \mu \mathrm{L}, 75 \mu \mathrm{mol} \mathrm{NH}$ ) and triethylamine $(21 \mu \mathrm{L}, 150 \mu \mathrm{mol})$. The mixture was stirred under nitrogen for $6 \mathrm{~h}$ at room temperature; the contents were then diluted with $10 \mathrm{~mL}$ of $\mathrm{CH}_{2} \mathrm{Cl}_{2}$ and washed with $3 \times 5 \mathrm{~mL} 1 \mathrm{M} \mathrm{HCl}$. The $\mathrm{CH}_{2} \mathrm{Cl}_{2}$ layer was dried over anhydrous $\mathrm{MgSO}_{4}$, filtered and evaporated to yield a clear, colorless oil. This oil was subsequently washed with $3 \times 1 \mathrm{~mL} \mathrm{CDCl}_{3}$ and the residue retained to yield $2.5 \mathrm{mg}(21.9 \%$ yield) of a clear oil. ${ }^{1} \mathrm{H}$ NMR (DMSO-d $\left.6 / \mathrm{CDCl}_{3}, 400 \mathrm{MHz}\right) \delta 11.88(\mathrm{~s}, 1 \mathrm{H}), 7.14(\mathrm{~s}, 1 \mathrm{H}), 6.59$ (s, $1 \mathrm{H}), 2.49(\mathrm{~m}, 1 \mathrm{H}), 2.41(\mathrm{~m}, 1 \mathrm{H}), 1.71(\mathrm{~m}, 4 \mathrm{H}), 1.53(\mathrm{~m}, 1 \mathrm{H}), 1.41(\mathrm{~m}, 2 \mathrm{H}), 0.86(\mathrm{~s}$, $9 \mathrm{H}) ;{ }^{13} \mathrm{C}$ NMR (DMSO-d $\left.6 / \mathrm{CDCl}_{3}, 100 \mathrm{MHz}\right) \delta 177.0,176.5,38.6,37.7,37.3,32.4,27.7,27.6$, 27.0, 26.2; IR (KBr pellet, $\mathrm{cm}^{-1}$ ) 1233, 1256, 1656, 1703, 2956, 3210, 3426; HRMS (TOF ES + ) calculated for $\mathrm{C}_{12} \mathrm{H}_{21} \mathrm{NO}_{3}(\mathrm{M}+\mathrm{H})^{+}:$228.1599. Found: 228.1604.

\section{Kinetic Measurements}

Reactions were initiated by adding $60 \mu \mathrm{L}$ of a DMSO- $\mathrm{d}_{6}$ solution containing approximately 1 $\mathrm{mg}$ of $t$-butyl acid-amide to $540 \mu \mathrm{L}$ of buffer solution in $\mathrm{D}_{2} \mathrm{O}(125$ or $250 \mathrm{mM}$ phosphate for $\mathrm{pD} \sim 2.5, \sim 6.5$, and $\sim 7.5 ; 125$ or $250 \mathrm{mM}$ mellitic acid for $\mathrm{pD} \sim 5.0$; the ionic strength for all buffers was adjusted to 1 or 2 using sodium chloride). Narrow-range $\mathrm{pH}$ paper was used to measure the $\mathrm{pD}$ of each solution. The $\mathrm{pD}$ was taken as the " $\mathrm{pH}$ " indicated plus 0.5 , the correction factor for both of the buffers used. 6,13 The samples were maintained at $20( \pm 1)^{\circ} \mathrm{C}$ in a thermostatted room. The extent of each reaction was typically determined by integrating resolved signals of the reactant relative to product. For some reactions, the product amine was integrated relative to the residual protonated DMSO in the deuterated solvent. Data analysis and curve-fitting were performed using IGOR Pro, Version 4.0 for Windows (WaveMetrics, Inc.).

\section{Computational Details}

Molecular mechanics calculations were performed using HyperChem ${ }^{\mathrm{TM}}$ Release 5.11 Pro for Windows (Hypercube, Inc.). The MM+ force field with the block-diagonal Newton-Raphson algorithm was employed, and all minimizations were terminated with mean square gradient of $0.05 \mathrm{kcal} /(\AA \mathrm{mol})$ or less.

\section{Supplementary Material}

Refer to Web version on PubMed Central for supplementary material.

\begin{abstract}
Acknowledgements
We are grateful to the National Institutes of Health (R15 GM63776) and to the Amherst College Faculty Research Award Program, as funded by the H. Axel Schupf ' 57 Fund for Intellectual Life, for financial support. In addition, this work was supported by the National Science Foundation-sponsored MRSEC and RSEC Centers at the Polymer Science and Engineering Department (University of Massachusetts, Amherst). We also thank the Howard Hughes Medical Institute for support of J.J.G. (through an Undergraduate Biological Sciences Education Program award to Amherst College). Finally, we thank Professor Sandra Burkett for recording the infrared spectrum of derivative $\mathbf{1 1 .}$
\end{abstract}

\section{References}

1. Menger FM, Ladika M. J Am Chem Soc 1988;110:6794-6796.

2. Smith RM, Hansen DE. J Am Chem Soc 1998;120(35):8910-8913.

3. Radzicka A, Wolfenden R. J Am Chem Soc 1996;118:6105-6109.

4. Menger FM, Ladika M. J Org Chem 1990;55:3007-3009. 
5. Curran TP, Borysenko CW, Abelleira SM, Messier RJ. J Org Chem 1994;59:3522-3529.

6. Dougan ML, Chin JL, Solt K, Hansen DE. Bioorg Med Chem Lett 2004;14:4153-4156. [PubMed: 15261260]

7. Armitage BJ, Kenner GW, Robinson MJT. Tetrahedron 1964;20:723-739.

8. McCall MA, Caldwell JR, Moore HG, Beard HM Jr. J Macromol Sci Chem 1969;3:911-926.

9. Word JM, Lovell SC, LaBean TH, Taylor HC, Zalis ME, Presley BK, Richardson JS, Richardson DC. J Mol Biol 1998;285:1711-1733. [PubMed: 9917407]

10. Word JM, Lovell SC, Richardson JS, Richardson DC. J Mol Biol 1998;285:1735-1747. [PubMed: 9917408]

11. Gilli G, Bertolasi V, Bellucci F, Ferretti V. J Am Chem Soc 1986;108:2420-2424.

12. Wolfenden R. Chem Rev 2006;106:3379-3396. [PubMed: 16895333]

13. Schowen KB, Schowen RL. Methods Enzymol 1982;87:551-6066. [PubMed: 6294457] 

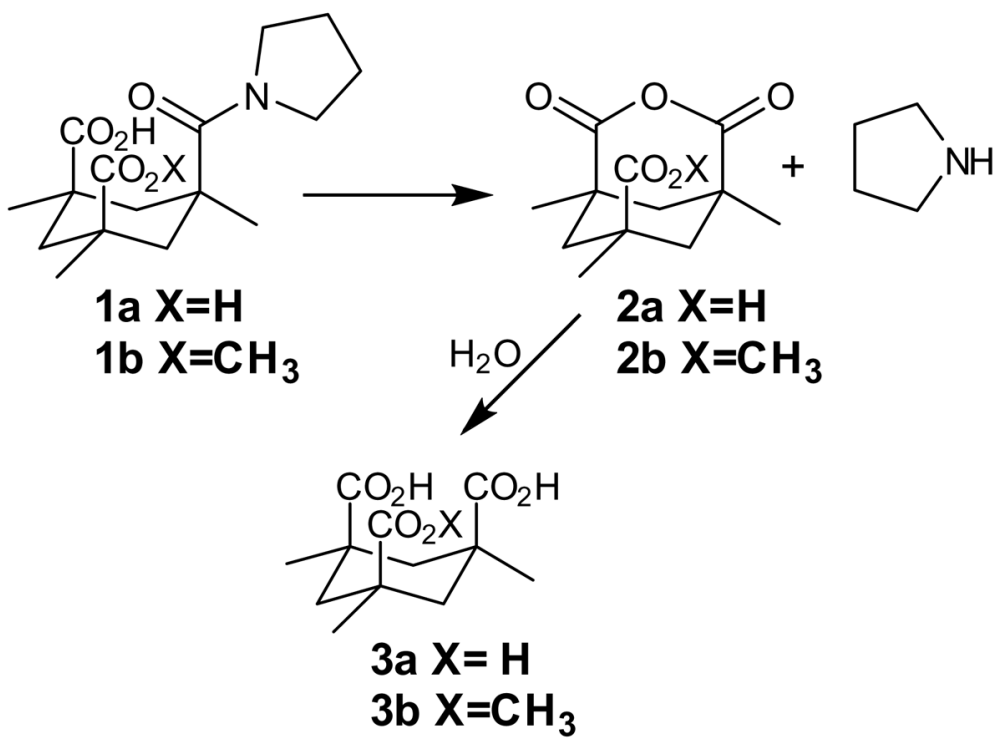

Figure 1. Pyrrolidyl Amide Cleavage 


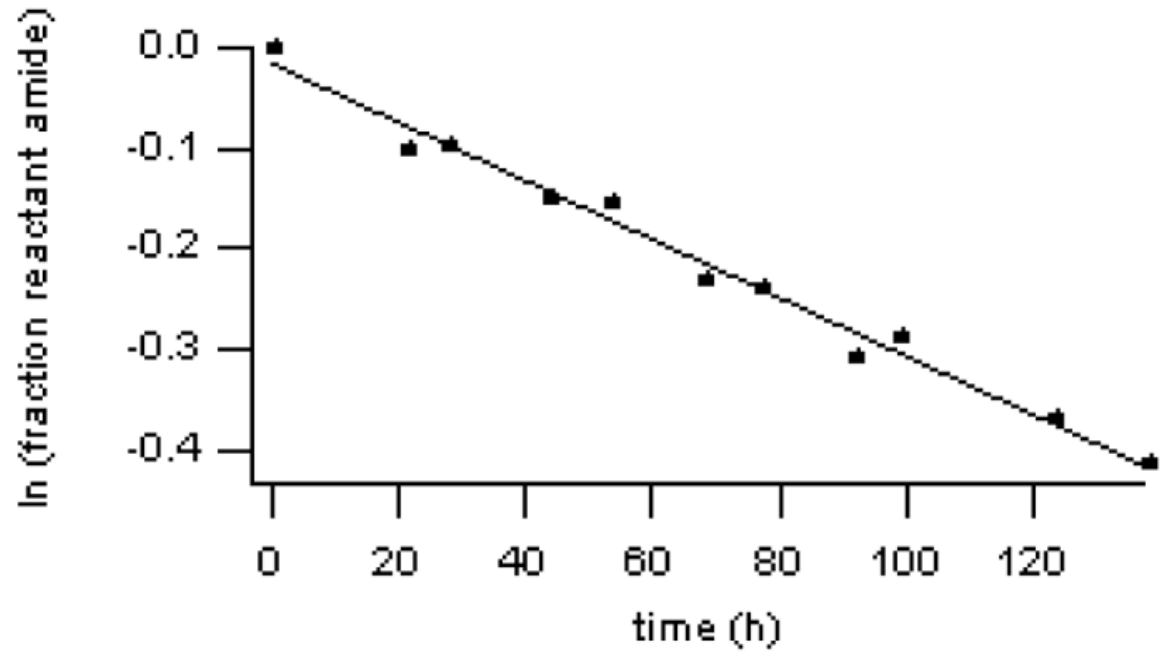

Figure 2. Reaction Kinetics of $t$-Butyl Acid-Pyrrolidyl Amide 9 at pD 5.5 


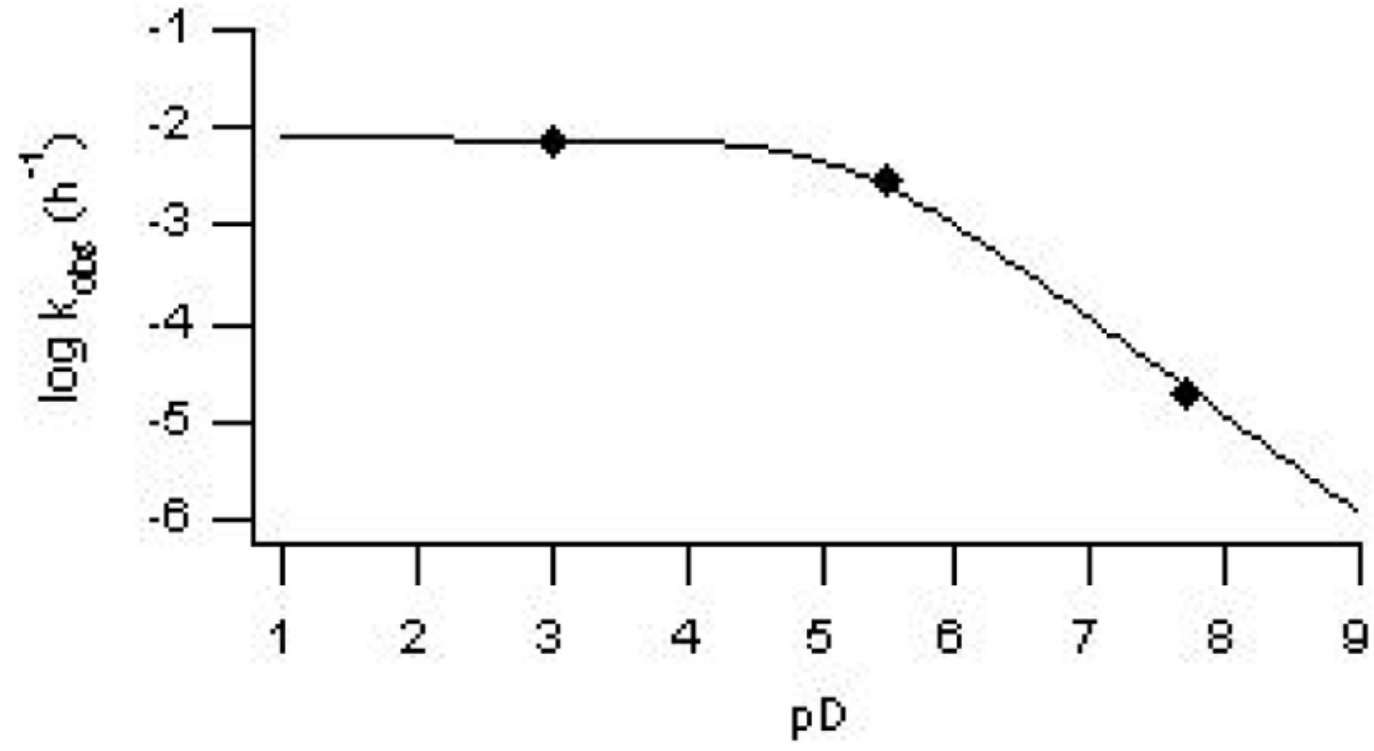

Figure 3. Plot of $\log k\left(\mathrm{~h}^{-1}\right)$ vs. pD for $t$-Butyl Acid-Pyrrolidyl Amide 9 


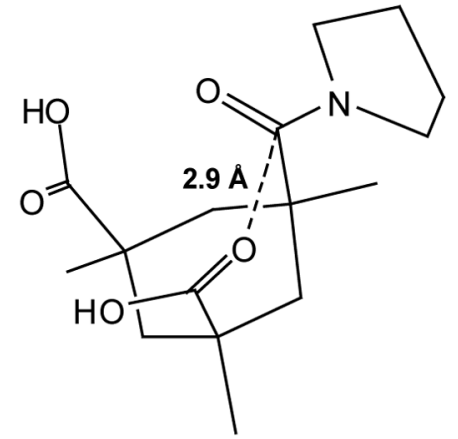

Kemp's diacid-pyrrolidyl amide derivative 1a

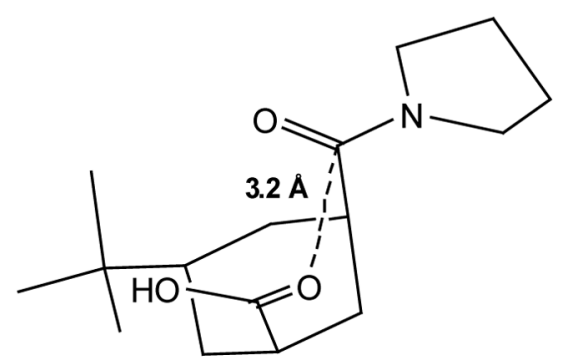

$t$-butyl acid-pyrrolidyl amide derivative 9

Figure 4. Conformations of Pyrrolidyl Derivatives 1a and 9 


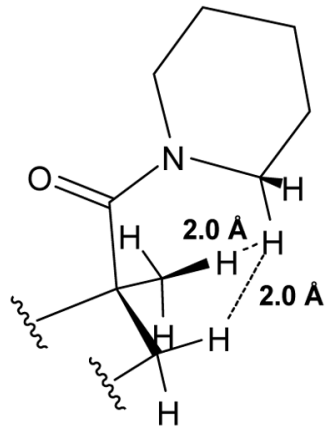

Kemp's diacid-piperidyl amide derivative 7

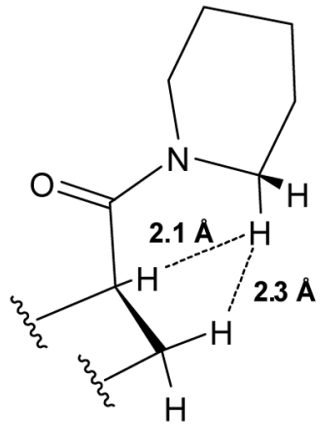

$t$-butyl acid-piperidyl amide derivative $\mathbf{8}$

Figure 5. Nonbonded Interactions in Piperidyl Derivatives 7 and 8 


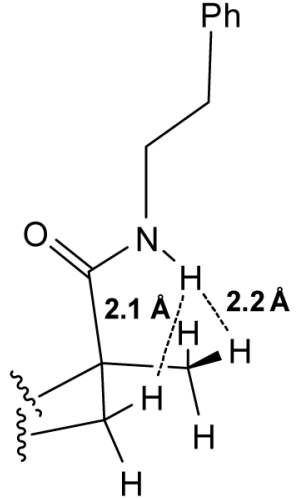

Kemp's diacid-phenethyl amide derivative $\mathbf{6 a}$

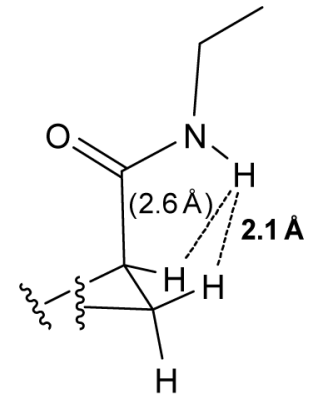

$t$-butyl acid-ethyl amide derivative $\mathbf{1 0}$

Figure 6. Nonbonded Interactions in Secondary Amide Derivatives 6a and 10 
Data for $t$-Butyl Derivatives 8-11

\section{Table 1}

\begin{tabular}{|c|c|c|c|c|}
\hline Compound & Rate constant $\left(k_{\text {ind }}\right)$ & $t_{1 / 2}$ & $K_{\mathrm{a}}\left(\right.$ in $\left.\mathrm{D}_{2} \mathrm{O}\right)$ & $\mathrm{p} K_{\mathrm{a}}\left(\right.$ in $\left.\mathrm{D}_{2} \mathrm{O}\right)$ \\
\hline$t$-butyl acid-piperidyl amide 8 & $0.32( \pm 0.04) \mathrm{h}^{-1}$ & $2.2 \mathrm{~h}$ & $7.8( \pm 1.4) \times 10^{-6}$ & 5.1 \\
\hline$t$-butyl acid-pyrrolidyl amide 9 & $7.70( \pm 1.5) \times 10^{-3} \mathrm{~h}^{-1}$ & $90 \mathrm{~h}$ & $6.7 \pm 1.9) \times 10^{-6}$ & 5.2 \\
\hline$t$-butyl acid-ethyl amide $\mathbf{1 0}$ & $3.85( \pm 0.2) \times 10^{-4} \mathrm{~h}^{-1}$ & $1800 \mathrm{~h}$ & $1.1( \pm 0.1) \times 10^{-6}$ & 6.0 \\
\hline$t$-butyl acid-primary amide 11 & $2.14( \pm 0.2) \times 10^{-3} \mathrm{~h}^{-1}$ & $324 \mathrm{~h}$ & $1.5( \pm 0.3) \times 10^{-6}$ & 5.8 \\
\hline
\end{tabular}


Table 2

Amide-Cyclohexyl Close Contact Distances

\begin{tabular}{|c|c|c|c|c|}
\hline Compound & $\mathbf{t}_{1 / 2}$ & Relative Reaction Rate & $\begin{array}{c}\text { Hydrogen- } \\
\text { hydrogen close } \\
\text { contact(s) }(\AA)\end{array}$ & $\begin{array}{l}\text { Extent of steric } \\
\operatorname{clash}(\mathrm{es})(\AA)^{b}\end{array}$ \\
\hline Kemp's diacid-piperidyl amide 7 & $\sim 0.5 \mathrm{~min}^{c}$ & 216,000 & $2.0,2.0^{d}$ & $0.4,0.4$ \\
\hline $\begin{array}{l}\text { Kemp's diacid-methylphenethyl } \\
\text { amide } \mathbf{5}\end{array}$ & $\sim 1 \min ^{e}$ & 108,000 & $2.0,2.2,2.3^{d}$ & $0.4,0.2,0.1$ \\
\hline Kemp's diacid-pyrrolidyl amide 1a & $1.7 \min ^{f}$ & 63,529 & $2.0 .2 .2 .2 .4^{d}$ & $0.4,0.2,0.0$ \\
\hline$t$-butyl acid-piperidyl amide 8 & $2.2 \mathrm{~h}$ & 818 & $2.1,2.3$ & $0.3,0.1$ \\
\hline Kemp's diacid-phenethyl amide $\mathbf{6 a}$ & $\sim 6 \mathrm{~h}^{e}$ & 300 & $2.0,2.2$ & $0.2,0.0$ \\
\hline Kemp's acid-ester-phenethyl amide $6 \mathbf{b}$ & $14 \mathrm{~h}^{f}$ & 129 & $2.0,2.2$ & $0.2,0.0$ \\
\hline$t$-butyl acid-pyrrolidyl amide $\mathbf{9}$ & $90 \mathrm{~h}$ & 20 & 2.2 & 0.2 \\
\hline$t$-butyl acid-primary amide $\mathbf{1 1}$ & $324 \mathrm{~h}$ & 6 & 2.1 & 0.1 \\
\hline$t$-butyl acid-ethyl amide $\mathbf{1 0}$ & $\begin{array}{c}75 \text { days }(1,800 \\
\mathrm{h})\end{array}$ & 1 & 2.1 & 0.1 \\
\hline
\end{tabular}

${ }^{a} \mathrm{C}-\mathrm{H}: \mathrm{C}-\mathrm{H}$ distances of less than $2.4 \AA$ (twice the van der Waals radius of a C-H hydrogen ${ }^{9}, 10$ ) and C-H:N-H distances of less than $2.2 \AA$ (the sum of 1.2

$\AA$, the van der Waals radius of a C-H hydrogen, and $1.0 \AA$, the van der Waals radius of a N-H hydrogen 9,10 ); C-H:N-H distances are shown in italics.

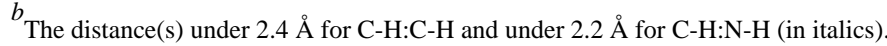

${ }^{c}$ Estimated through extrapolation of data in Ref. 6.

${ }^{d}$ Ref. 6.

${ }^{e}$ Estimated through extrapolation of data in Ref. 5.

$f_{\text {Ref. } 5 \text {. }}$ 